\title{
WYMIARY DEEUROPEIZACJI
}

\author{
DIMENSIONS OF DE-EUROPEANIZATION
}

Spasimir Domaradzki*

\begin{abstract}
ABSTRAKT
Artykuł stanowi teoretyczną refleksję nad istotą pojęcia deeuropeizacji. Krytyczna ocena koncepcji europeizacji pozwala zidentyfikować jej wewnętrzne słabości, ograniczające jej możliwości poznawcze. Tendencja do jednoznacznie pozytywnej konotacji oraz marginalizowanie trudności powstających na skutek procesu integracji tworzą niepełną rzeczywistość. Stąd pojawia się konieczność pochylenia się nad jej antytezą - deeuropeizacją. W oparciu o analizę dostępnej literatury na temat deeuropeizacji artykuł porządkuje istniejące wymiary deeuropeizacji oraz identyfikuje jej charakterystyczne cechy.
\end{abstract}

Słowa kluczowe: europeizacja; deeuropeizacja; przeciweuropeizacja; wymiary deeuropeizacji; krytyczna europeizacja
The paper offers a theoretical reflection on the substance of the meaning of the term 'DeEuropeanization'. A critical assessment of the concept of Europeanization reveals a tendency towards an unequivocally positive connotation and the subconscious marginalization of the difficulties caused by the integration process. These aspects underline its inherent cognitive weakness. Hence, there is a need for a deeper reflection on its antithesis - De-Europeanization. Based on the available De-Europeanization literature, this paper aims to organize the existing dimensions of De-Europeanization and identify its characteristic features.

Keywords: Europeanization; De-Europeanization; Counter-Europeanization; dimensions of De-Europeanization; critical Europeanization

* Uczelnia Łazarskiego w Warszawie, Wydział Ekonomii i Zarządzania. 
Niniejszy artykuł ${ }^{1}$ powstał w odpowiedzi na potrzebę znalezienia najbardziej pojemnej teorii europeizacji, która uwzględniałaby zarówno jej pozytywny, jak i negatywny wymiar. W gąszczu wielu alternatywnych, uzupełniających się, a także zachodzących na siebie prób jej zdefiniowania, stopniowo wyłaniał się problem aksjologicznej jednokierunkowości europeizacji, która postrzegana jest jako nieodwracalny proces, a jej dobroczynny wpływ brany jest jako pewnik. Z drugiej strony, chociaż powoli i z odmiennych perspektyw, przebijają się opracowania nastawione bardziej krytycznie wobec europeizacji, poszukujących nowej wizji konceptualizacji procesów integracji europejskiej. Co więcej, stopniowo w literaturze coraz częściej pojawia się termin deeuropeizacja, który najprościej byłoby traktować jako antonim europeizacji. Problem jednak w tym, że w definicyjnym gąszczu pojęcia europeizacji nie jest do końca jasne, czym jest w swojej istocie deeuropeizacja i czy stanowi jej antonim. Do nielicznych należą osoby, które jednoznacznie przeciwstawiają oba terminy (Mazurkiewicz, 2001). Dlatego celem artykułu jest podjęcie próby wyjaśnienia, czym jest deeuropeizacja i w jakim wymiarze może ona być traktowana jako antonim dla europeizacji. W pierwszej kolejności należy zastanowić się, czy i dlaczego deeuropeizacja jest potrzebna? Stąd krytycznej analizie poddane zostaną inkluzywność oraz możliwości poznawcze definicji europeizacji. Następnie przez skonfrontowanie istniejących koncepcji traktujących o antytezie europeizacji oraz uporządkowanie obecnych sposobów jej zastosowania zostaną zarysowane dominujące percepcje terminu. W ostatniej części zostaną zaproponowane odmienne wymiary deeuropeizacji. W konkluzjach zostaną rozpoznane charakterystyczne cechy deeuropeizacji.

Odmienne podejścia teoretyczne zwracają uwagę na specyfikę procesów, akcentując bądź te zachodzące stricte w ramach procesu integracji, bądź też szerszych interakcji w ramach zjednoczonej Europy. Brak jest też jednoznacznej zgody co do obszaru badawczego koncepcji europeizacji (Grosse, 2012, s. 9-12; Olsen, 2002, s. 922; Graziano, Vink 2012, s. 37; Bache, George, Bulmer, 2011, s. 37, Radaelli, 2002). Obejmuje on nie tylko państwa członkowskie, ale również państwa kandydujące, najbliższe otoczenie międzynarodowe, a nawet oddziaływanie UE daleko poza granicami Europy. Nie ma również zgody co do ram czasowych, gdy dla jednych jest to proces bezpośrednio związany z integracją (Ladrech, 1994;

1 Chciałbym podziękować Janowi Grzymskiemu oraz Henrykowi Hollendrowi, a także dwóm nieznanych mi recenzentom, których krytyczne uwagi były dla mnie niezwykle cennym drogowskazem. Wszelkie słabości w tekście są tylko moje. 
Radaelli, 2003), a dla innych jest o wiele dłuższy (Mazurkiewicz, 2001) i obejmujący długotrwałe procesy zachodzące na kontynencie europejskim. Niniejsze rozważania podążą za definicją europeizacji K. Featherstone jako wewnętrznej adaptacji instytucji, polityk i aktorów na skutek członkostwa w UE (Featherstone, 2003), akcentując tym samym rolę procesu integracji europejskiej. Nie sposób jednak uciec również od poglądów, które nawet jeżeli wykraczają poza stawiane ramy badawcze, uzupełniają niniejsze rozważania.

\section{NEGATYWNE SKUTKI EUROPEIZACJI}

Pośród modeli teoretycznych w sposób zwarty przedstawionych przez R. Riedla (2014, s. 26-28) definicja europeizacji Claudio Radaellego (2003) w największym stopniu spełniała stawiane wymogi. Według niego europeizacja to „zestaw procesów, poprzez które dynamika polityczna, ekonomiczna i społeczna UE staje się częścią wewnętrznego dyskursu, tożsamości, struktur politycznych i publicznych polityk państw członkowskich. Identyfikuje on cztery sposoby, którymi państwa członkowskie odpowiadają na politykę UE: akomodacja, czyli przystosowanie struktur, polityk, debat, tożsamości wewnętrznych; transformacja, czyli przekształcenie tych elementów w sytuacji, gdy polityka UE stawia im wyzwanie; inercja, kiedy brak jest woli politycznej do przeprowadzenia zmian; redukcja, gdy dany obszar polityki wewnętrznej aktywnie występuje przeciwko regulacji UE” (także Riedel, 2014, s. 28).

Definicja Radaellego pozwala wprowadzić do dyskusji kluczowe dla niniejszych rozważań pytanie, czy „europeizacja” uwzględnia również negatywne skutki samego procesu? W kontekście przytoczonej definicji, skoro zdefiniowane inercja i redukcja uwzględniają oddziaływanie sił stawiających opór, można pokusić się o stwierdzenie, że właśnie tak jest. Tym bardziej, że zastanawiając się nad pytaniem o to, jakie zmiany powoduje europeizacja, Radaelli rozpoznaje „oszańcowanie” (entrenchment) obok „inercji”, „absorbcji oraz „transformacji”. Termin o tyle trafny, że w swojej istocie zakłada „okopanie się” polityki krajowej, która na skutek bodźca europeizacyjnego staje się mniej europejska, niż była (Radaelli, 2000, s. 15). Ta trafna obserwacja wsparta jest jednak przykładem, który ujawnia pozytywistyczny charakter rozważań o europeizacji. Otóż przejawem tegoż „okopania się” miał być wzrost interwencji ze strony państwa, zamiast liberalizacji, w dziedzinie regulacji transportu drogowego. Innymi słowy europeizacja postrzegana jest przez Radaellego nie tylko jako proces techniczny, ale 
także proces o namacalnym zabarwieniu ideologicznym. Wydaje się, że o wiele bardziej użyteczną interpretacją „oszańcowania” byłoby podkreślenie faktu stawiania świadomego oporu w dążeniu do zachowania istniejącego status quo.

Co więcej, również w kontekście wpływu europeizacji na partie polityczne Radaelli zwraca uwagę na ważki przykład Maira, który zauważa pośredni wpływ integracji europejskiej na systemy partyjne. Otóż „gdy w trakcie wyborów krajowych dyskutowane są tematy polityczne, które rozstrzygane są na innym poziomie (europejskim), wyborcom proponuje się zajęcie stanowiska, które najprawdopodobniej będzie miało mały albo niewielki wpływ na proces decyzyjny" (Radaelli 2000, s. 12). Na ten problem już wcześniej zwracała uwagę Vivien Schmidt, podkreślając negatywny wpływ integracji na sposób funkcjonowania demokracji na poziomie krajowym (Schmidt 1997). W kontekście państw kandydujących Geoffrey Pridham wskazuje na dominację administracyjnej efektywności nad wartością demokracji partycypacyjnej (2006, s. 391). Dekadę później Sedelmeier zauważył negatywny wpływ UE na parlamenty krajowe, a także umacnianie władzy wykonawczej względem ustawodawczej przez preferowanie szybkiej ścieżki debaty nad prawem oraz szybkie działanie przed głęboką deliberacją. Cel członkostwa dał egzekutywie więcej władzy do unikania parlamentu i do usprawiedliwienia centralizacji procesu decyzyjnego z powodu pilności wyzwania (Sedelmeier 2011, s. 21).

W takim przypadku europeizacja przyczynia się do procesu de-polityzacji, obojętności oraz wycofania się z życia społecznego, co można uznać za jedną z odnóg problemu deficytu demokracji. Radaelli zwraca jednak uwagę, że w swojej istocie następuje „re-polityzacja” na poziomie europejskim. Nie odpowiada jednak na nasuwające się pytanie, czy owa „re-polityzacja” posiada tę samą wartość jakościową jak wcześniejsza polityzacja na poziomie krajowym? Innymi słowy, czy wypełnia próżnię powstałą na skutek opisanego przez Maira procesu, czy też tworzy całkowicie odmienny i nieporównywalny proces, który w kontekście deficytu demokracji na poziomie unijnym oraz namacalnej politycznej demobilizacji na poziomie społeczeństw państw członkowskich podważa zasady demokracji, a tym samym i sam proces integracji? Wydaje się, że dominującą tendencją w tym przypadku jest uwzględnienie prób obstrukcji jako część procesu europeizacji, ponieważ i tak prowadzi do unifikacji, która w swojej istocie jest sednem europeizacji.

Takie rozumowanie europeizacji coraz trudniej wytrzymuje jednak konfrontację z rzeczywistością, gdy ewoluujący proces integracji europejskiej dostarcza przykłady trudności w procesie unifikacji kolejnych podmiotów 
(państw, regionów, władz lokalnych, społeczności) do norm unijnych. Presja adaptacyjna (Riedel 2014, s. 27; Caporaso 2007 s. 27-28) - stanowiąca główne ogniwo procesu - nie zawsze prowadzi do jakościowo lepszego stanu w porównaniu do okresu sprzed jej uruchomienia. Co więcej, wraz ze wzrostem siły i kompetencji unijnych instytucji w procesie integracji rośnie również świadomy opór na różnych poziomach, który w literaturze przedmiotu opisuje się jako „hamująca niezgoda” (constraining dissensus). Aktualne przy tym pozostaje pytanie o to, czy wspomniana niezgoda jest nadal częścią procesu europeizacji, czy też stanowi przyczółek do konceptualizacji antonimu europeizacji, czyli de-europeizacji?

Dominujące w anglojęzycznej i polskiej literaturze definicje europeizacji zwracają szczegółową uwagę na jej systemowy (Ladrech, 1994, Olsen 2002, Grosse, 2012, Riedel 2014) oraz kulturowy czy też aksjologiczny (Mair, 2004) aspekt. Jak zauważa T.G. Grosse (2012), mówiąc o kulturowym aspekcie europeizacji, mówi się o nim rzadziej, gdyż jest on „selektywny, niespójny i powierzchowny, co osłabia symboliczny i kulturowotwórczy wymiar europeizacji” (s. 14-15). Nawet jednak wytyczając granicę między powyższymi wymiarami, należy zwrócić uwagę na to, że szereg badaczy zdaje sobie sprawę z trudnej do rozdzielenia relacji między sferą instytucjonalną a ideową. Tym samym dla niniejszego wywodu ważne jest poszukiwanie tych słabości przy konceptualizacji europeizacji, które są wspólne dla obu aspektów.

Stopniowy wzrost literatury na temat deeuropeizacji wskazuje na ujawniający się trend krytycznego myślenia o narzędziach poznawczych oferowanych przez istniejące konceptualizacje europeizacji. Chociaż poszukiwania w katalogach bibliotecznych terminu deeuropeizacja nie dostarczają zawrotnej ilości rekordów, należy zauważyć, że ich ilość wzrasta systematycznie od końca pierwszej dekady XXI wieku. F. Schimmelfenning (2007), T.A. Börzel oraz T.Risse (2009) podnoszą konieczność poświęcenia większej uwagi negatywnym skutkom integracji. Również prace P. Copelanda (2016), G. Raagmaa, T. Kalvet oraz R. Kaselalu (2014), czy A. Cianciary (2015) próbują uchwycić procesy deeuropeizacyjne w kontekście konkretnych polityk czy też państw (Yilmaz, 2016). Z kolei prace Hans J. Trenza (2014), A. Agha (2015), a także w polskiej literaturze Jarosława Jańczaka (2014) nie tylko zauważają konieczność zagospodarowania negatywnego wymiaru europeizacji, ale również przedstawiają ważne rozważania teoretyczne w kierunku jej konceptualizacji. 


\section{SŁABOŚCI EUROPEIZACJI}

Wśród krytycznych refleksji na temat procesu europeizacji należy podkreślić właśnie kwestię przyjęcia jako pewnik nieuchronności zjawiska, które dominuje w badaniach. Już w 2003 r. S. Jacquot i C. Woll trafnie zauważyły, że w instytucjonalistycznym nurcie badań nad europeizacją Unia Europejska traktowana jest jako zmienna niezależna (2003, s. 2). Jak zauważa Trenz (2014) za M. Eigmuller i S. Mau (2010), procesowi europeizacji towarzyszy entuzjazm wynikający, między innymi, z uznania się środowiska studiów europejskich za odkrywców nowego bytu politycznego (polity), nowego systemu czy nawet nowego społeczeństwa (s. 3). Można zatem stwierdzić, że chęć kreowania rzeczywistości dominuje nad próbami jej wyjaśnienia.

Kolejną, pokrewną słabością samego terminu europeizacji jest nadanie mu znaczenia wartościującego, dobitnie zobrazowanego przez stwierdzenie Thomasa Schmida (2016) „Niebo integracji i piekło dezintegracji” (s. 55). W ten sposób europeizacja rozumiana jako techniczny termin służący do uporządkowania rzeczywistości staje się również narzędziem normatywnego osądu w rękach zwolenników postępującego procesu integracji. Należy przy tym podkreślić, że taki sposób myślenia o procesie jest rozpowszechniony zarówno wśród naukowców, dziennikarzy i publicystów. Jak zauważa Trenz (2014), „terminologia europeizacji jest używana do potwierdzenia telos integracji i wiarę w możliwości nawigowania ponadnarodowego modelu zarządzania” (s. 16). W tym samym duchu A. Gąsior-Niemiec (2005) identyfikuje UE jako swoistą „wspólnotę epistemiczną” (s. 77). Badania nad europeizacją są nadal wykorzystywane, bezpośrednio lub pośrednio, do legitymizacji UE jako systemu zarządzania (governance), który przez kierowanie, interwencje i regulacje rozwija nadrzędne możliwości rozwiązywania problemów i wyższą legitymizację w sensie wydajności i skuteczności (Trenz, 2016, s. 16). Odwołując się do koncepcji Maira (2004, s. 342), porównania europeizacji z nacjonalizacją, można stwierdzić, że europeizacja jest niczym innym jak opisem tworzenia nowego bytu politycznego, którego powstanie przyjmuje się jako pewnik. Dlatego nic, co jest związane z europeizacją, nie może być rozsadzające czy też złe - jest najwyżej dłuższą drogą do celu.

Odejście od deskryptywnej i przejście do normatywnej roli europeizacji jest przejściem od idei do ideologii, która wykrzywia istniejący obraz rzeczywistości w kierunku stałego akcentowania pozytywnego wymiaru procesu oraz koncentrowaniu się na jego jednoznacznie korzystnym wpływie na rzeczywistość. Jak zauważa Copeland (2016), słabością istniejącej literatury jest dorozumiane zało- 
żenie, że europeizacja jest ciągłym „pozytywnym” procesem, lecz ma niewiele do powiedzenia, gdy zmiana rządów prowadzi do depriorytetyzacji unijnych celów na poziomie krajowym (s. 1126). W tak definiowanej europeizacji niekorzystne konsekwencje wynikające z procesu dostosowywania się postrzegane są jako „skutki uboczne”, którym nie warto poświęcać wiele uwagi. Przede wszystkim dlatego, że są one ceną, jaką należy zapłacić, dążąc do wdrożenia ideologicznego kanonu, jakim staje się europeizacja. O mocno zideologizowanym zabarwieniu terminu europeizacji niech chociaż świadczy fakt, że przez dłuższy czas w literaturze nie pojawiał się jego antonim, niejako zakładając, że jest to proces jednokierunkowy.

Na ową słabość badań nad europeizacją wskazywał już w 2007 r. Schimmelfennig (2007), podkreślając, że „niewiele uwagi zostało poświęconej niezamierzonym, czy też negatywnym skutkom europeizacji w literaturze (s. 14). Również Börtzel i Risse (2009) zauważyli, że „o ile rola Unii Europejskiej i jej państw członkowskich, jako promotorów normatywnych i przyczynowo-skutkowych idei jest całkiem przyzwoicie zbadana, niewiele wiemy o skutkach tych prób dyfuzji, które często napotykają na opór i kontestację na poziomie krajowym" (s. 10).

\section{KU DEEUROPEIZACJI}

Rozpoznanie początków krytycznego myślenia o europeizacji nie jest łatwe. Dla niektórych autorów ustanowienie Unii Europejskiej na mocy Traktatu z Maastricht było tym przełomowym wydarzeniem, które wymusiło zmianę myślenia o procesie integracji, funkcjonującego do tej pory na zasadzie „dorozumianej zgody" (permissive consensus) (Chryssochoou, 2010, s. 378; Kröger, 2014; Lemardeley, 2013). Przykłady tej oddolnej opozycji można zauważyć chociażby w kontekście utworzenia strefy Schengen, a następnie Europejskiej Unii Monetarnej w ramach Traktatu z Maastricht i związanych z nimi duńskim, brytyjskim i irlandzkim opt-outem, a także z norweskimi referendami odrzucającymi członkostwo.

Nawet jeżeli uznamy, że dorozumiana zgoda w kwestii integracji wśród państw członkowskich przetrwała wejście w życie Traktatu o Unii Europejskiej, to od początku XXI wieku mamy do czynienia ze stopniowym przejściem państw w kierunku „hamującej niezgody”. Wyzwania związane z rozszerzeniami z 2004 i 2007 r., pomysł na Traktat Konstytucyjny, wysiłki na rzecz zwiększenia znaczenia 
instytucji unijnych w obszarze high politics, czyli bezpieczeństwa wewnętrznego i zewnętrznego oraz polityki zagranicznej (Schimmelfennig, Rittberger, 2006, s. 81) oraz dążenie do odgrywania globalnej roli przez UE, zmusiły państwa członkowskie do głębszej refleksji nad pytaniem o kształt i ramy procesu integracji. Schmid uważa, że czynniki, które złożyły się na pojawienie się myślenia o końcu Unii, to euro, Rosja, rozszerzenie na wschód, kwestia uchodźców, ustrój wewnętrzny Unii Europejskiej oraz wyjście Brytyjczyków (2016, s. 31). Jednocześnie, poczynając od kryzysu gospodarczego, piętrzące się i nierozwiązywalne problemy wewnętrzne i zewnętrzne Unii Europejskiej również wytyczyły granice wspólnego myślenia o Europie. Konieczność dokonania głębszej refleksji nad postępującym procesem integracji oraz piętrzące się zewnętrzne i wewnętrzne wyzwania stworzyły podatny grunt do zakwestionowania dogmatycznej jednokierunkowości europeizacji.

Podsumowując, ewolucja procesu integracji europejskiej, a wraz z nią i wzrost badań i rozważań nad procesem europeizacji, mniej lub bardziej celowo obierały charakter prointegracyjnej apologetyki, która samoistnie wykluczała możliwość krytycznej samorefleksji. Nawet gdy uwzględnia się negatywne skutki bądź też opór wobec europeizacji, paternalistycznie sprowadza się je do roli mało istotnych szczegółów. Dlatego w kolejnej części należy odnieść się do istniejących już prób zidentyfikowania przeciwieństwa dla europeizacji, zarysować pewne trendy myślowe i na koniec przedstawić własną propozycję deeuropeizacji.

\section{W POSZUKIWANIU DEFINICJI}

Chociaż niezbyt liczne, w katalogach bibliotecznych pojawiają się już opracowania pod hasłem „deeuropeizacja”. Ponadto również w polskiej literaturze nie brakuje rozważań nad problemami negatywnego wymiaru europeizacji. Luki w myśleniu o europeizacji zauważa Agnieszka Cianciara (2015), pytając o jej „granice w sensie namacalnych przykładów instrumentalizacji tego procesu przez partie polityczne i ich liderów” (s. 7). Jednak, jak do tej pory, najbardziej pogłębionym i podejmującym się intelektualnego wysiłku zaproponowania teoretycznych ram tegoż przeciwieństwa europeizacji jest opracowanie Jarosława Jańczaka (2014), który używa terminu „przeciweuropeizacja” (s. 94-104).

Należy zgodzić się ze stawianą przez niego tezą, że „dla badania reakcji $\mathrm{w}$ formie przeciweuropeizacji konieczne jest kompleksowe ujęcie procesu europeizacji, czyli uwzględniające wielorakość istniejących podejść i definiujące nie 
tylko charakter procesu i jego dynamikę, ale także jego cele i przebieg" (Jańczak, 2014, s. 94). Kreśląc możliwie najszersze ramy koncepcyjne, Jańczak uwzględnia formalny i nieformalny wymiar, wszystkie możliwe kierunki oraz obszary (np. system polityczny, normy i wartości, kultura polityczna etc) wspólnoty politycznej, procesów podejmowania decyzji, polityk sektorowych oraz dwóch głównych aktorów: Unię Europejską oraz państwo narodowe, nieograniczone przy tym faktem członkostwa lub nie (Jańczak, 2014, s. 95). Usadawiając swój wywód w przytoczonej również w niniejszym opracowaniu definicji C. Radaellego, definiuje przeciweuopeizację jako działania „w wyniku, których polityczna i ekonomiczna dynamika Wspólnot nie staje się (czyli: staje się wolniej od przyjętych założeń, aplikacja zostaje zahamowana lub następuje jej regres) częścią logiki organizacyjnej narodowej polityki oraz tworzenia różnorodnych polityk sektorowych” (Jańczak, 2014, s. 96-97). Dla Jańczaka „istotą procesu przeciweuropeizacji powinno być więc oddziaływanie kontekstu terytorialnego oraz systemowego (gdzie na pierwszy składają się czynniki globalne, regionalne i europejskie, na drugi normy i idee, instytucje oraz pozostali aktorzy), którego wynikiem jest odwrócenie (spowolnienie, zatrzymanie lub regres) transformacji europeizacji systemu. Są to więc sposoby i narzędzia stosowane celem zahamowania lub zawrócenia aplikacji rozwiązań wspólnotowych do systemów wewnętrznych europeizujących się państw" (Jańczak, 2014, s. 96-97). Biorąc pod uwagę definicję Radaellego, można zatem stwierdzić, że w tym przypadku przeciweuropeizacja jest równa nie-europeizacji, czyli oporowi wobec zewnętrznych prób oddziaływania. Należy jednak przypomnieć, jak już była mowa wyżej, że samo uwzględnienie oporu - w rozumieniu Radaellego jako inercja i redukcja wobec europeizacji - nie czyni jej koniecznie deeuropeizacją, gdyż uwzględniana jest jako jeden z możliwych scenariuszy odpowiedzi na presję integracyjną. Innymi słowy samo spowolnienie czy brak europeizacji nie oznacza jeszcze, że mamy do czynienia z deeuropeizacją.

Opierając swoją koncepcję na linearnym postrzeganiu problemu, Jańczak proponuje budowę modelu przeciweuropeizacji, uwzględniającego przedmiot, podmiot oraz określenie przeciweuropeizujących aktorów, czyli źródło przeciweuropeizacji (Jańczak 2014 s. 97-98). Zauważa przy tym, że objawy przeciweuropeizacji będą różnić się w kwestii przebiegu procesu ze względu na formalne relacje względem Unii Europejskiej. Państwa członkowskie, państwa kandydujące czy też państwa trzecie będą borykały się z odmiennymi problemami. Polemiczne natomiast pozostają próby usystematyzowania przejawów przeciweuropeizacji. W przypadku państw członkowskich Jańczak zalicza euro- 
sceptycyzm i kastomizację, rozumianą jako „dostosowywanie Unii do własnych potrzeb, tak w wymiarze terytorialnym, jak i systemowym. Pierwsza polega na przyciąganiu uwagi ugrupowania integracyjnego do specyficznego regionu. Druga prowadzi do penetracji systemu wspólnotowego przez narodowe normy i idee, instytucje oraz innych aktorów" (Jańczak, 2014, s. 99). O ile w przypadku eurosceptycyzmu pozostaje on obszarem intelektualnej kontestacji procesu europeizacji, to sam w sobie nie jest jeszcze deeuropeizacją. Chyba że w ślad za integracyjnym dogmatem uznamy, że każda krytyka europeizacji jest przeciweuropeizacją. Nawet jeżeli w ramach szeroko pojętego nurtu eurosceptycyzmu mamy do czynienia z przejawami radykalnie anty-unijnych propozycji, to do ich realizacji wymagana jest jeszcze wola większości wyborców, której na chwilę obecną nie ma.

Natomiast w kontekście kastomizacji Jańczak trafnie zauważa, że istnieje możliwość, gdy „elementy struktur państw narodowych stają się częścią systemu wspólnotowego oraz częścią narodowych systemów innych państw członkowskich. Zamiast europeizacji państwa członkowskiego X następuje x-yzacja systemu europejskiego”. Wyrażałem podobne obawy, pisząc o „bułgaryzacji” Unii Europejskiej (Domaradzki, 2013). Jednak Caporaso zauważa, że sprzężenie zwrotne również zagospodarowuje fakt, że w ramach procesu europeizacji elementy narodowego systemu mogą przedostać się do procesu integracji (Riedel, 2014, s. 27). Ważna jest jednak ich istota i jakość, która może przekładać się na wzmocnienie procesu integracji lub jego osłabienie. Dla przykładu, jeżeli do grona państw skutecznie zwalczających korupcję dołączy państwo, które ma problemy z praworządnością, to w mniemaniu wielu doprowadzi pod presją europeizacyjną do rozwiązania problemu. Nie jest jednak jasne, dlaczego wyklucza się również możliwość wystąpienia odwrotnego efektu, gdy członkowie UE zauważą, że również państwo o niższym standardzie może być członkiem i w sposób podświadomy doprowadzić do obniżenia standardów antykorupcyjnych, opierając się na uzasadnieniu, że i „u innych tak jest”. W takiej sytuacji można stwierdzić, że dochodzi do deeuropeizacji rozumianej jako przedostanie się do procesu integracji praktyk, które w swojej istocie ustanawiają nowy - niższy - poziom jakości unifikacji, niż miał miejsce przed działaniem europeizacyjnym.

Biorąc pod uwagę powyższe, zasadnicze i trafne są obserwacje dotyczące państw kandydujących, w kontekście dynamiki systemu po uzyskaniu statusu członka UE. W przypadku europeizacji formalnej na potrzeby członkostwa nie brakuje przykładów, gdy wraz z ustaniem elementu warunkowości można oczekiwać powrotu do rozwiązań rzeczywiście zakorzenionych w strukturach danego 
państwa (Jańczak, 2014, s. 100-101). Warto chociażby wspomnieć tutaj o wątpliwościach związanych z bułgarskim i rumuńskim wymiarem sprawiedliwości, czy też estońskimi problemami dotyczącymi ochrony mniejszości narodowych. Jest to również w moim mniemaniu kolejny obszar deeuropeizacji, rozumianej jako słabość europeizacji, która wymuszając formalne zmiany, napotyka na zbyt mocny opór lokalnych zwyczajów.

Podsumowując, ciekawa propozycja Jańczaka, wprowadzająca termin przeciweuropeizacji, zasługuje na uwagę ze względu na szereg trafnych i potrzebnych sformułowań. Z drugiej strony należy zauważyć, że koncepcja ta oparta jest na zaadoptowaniu teoretycznych ram europeizacji i rozciągnięciu ich na wszystkie, lub przynajmniej dużą większość, krytycznych przejawów wobec integracji europejskiej. Takie uniwersalne ramy mogą pasować do przeciweuropeizacji, lecz dla poszukiwań teoretycznych ram deeuropeizacji są stanowczo za szerokie.

\section{WYMIARY DEEUROPEIZACJI}

Analizując istniejącą literaturę na temat deeuropeizacji, można rozpoznać dwa główne nurty w myśleniu o niej. Pierwszy to deeuropeizacja jako powrót do interesu narodowego czy też jako ucieczka od unijnego dogmatu, a drugi jako odejście od wartości.

\section{DEEUROPEIZACJA JAKO POWRÓT DO INTERESU NARODOWEGO}

Jednym z wymiarów, w którym można zarysować deeuropeizację, jest interakcja między interesem europejskim a interesem narodowym. Dla M. Romanowskiego i W. Czachura deeuropeizacja to proces, w którym w polityce zagranicznej państwa członkowskiego Unii Europejskiej następuje zmiana proporcji między interesem wspólnotowym a narodowym na rzecz tego drugiego (Czachur, 2010; Romanowski, 2015). Tym tropem podąża również stwierdzenie Copelanda, który w pracy Raagmaa dostrzega ideę deeuropeizacji jako deklarację politycznego establishmentu, że spójność z Unią Europejską nie jest priorytetem, oraz że istnieje inny interes narodowy (Copeland, 2016, s. 1124). Tak zdefiniowana deeuropeizacja akcentuje naturalny proces przerwania ciągłości interesów między poszczególnymi szczeblami (w tym przypadku unijnym i narodowym). 
Nie oznacza to jednak nierozwiązywalnego konfliktu między interesami, lecz oszacowanie korzyści płynących ze wspólnotowego i samodzielnego działania. Nie ma natomiast wątpliwości, że zaistnienie takiego procesu będzie równoznaczne $\mathrm{z}$ osłabianiem więzi powstałych $\mathrm{w}$ ramach procesu europeizacji.

Deeuropeizacja może być również rozumiana jako proces wycofania się z realizowanej w ramach Unii Europejskiej polityki (Copeland, 2016, s. 1124). Taka deprioretyzacja unijnych celów ma swoje źródła w zmianie politycznych elit na podstawie demokratycznego procesu. Punktem odniesienia w tym przypadku nie jest kwestia interesów, a sam proces, w którym polityka krajowa staje się mniej europejska niż była (Yilmaz, 2016). Jak trafnie zauważa Copeland (2016), deeuropeizacja stanowi proces wycofania się $\mathrm{z}$ danej polityki, połączony ze świadomą decyzją o odwróceniu wpływu europeizacji (s. 1126).

Dobrym przykładem tego toku rozumowania jest argument Z. Krasnodębskiego (2013), obnażający sztuczność i inżynierię polityczną procesu europeizacji, która odrzucała „politykę, w której zawiera się element walki, antagonizmu, rywalizacji i władzy, zastępując ją zarządzaniem, uzgadnianiem interesów”. Skoro „Europa miała w przyszłości mówić jednym głosem. Europejskie unisono miało być wyrazem całkowitej harmonii dusz". Właśnie proces odrzucania tego zniewolenia jest niczym innym jak deeuropeizacją, którą na podstawie rozważań Z. Krasnodębskiego można by określić jako powrót do wolności, definiowanej jako pluralizm myśli (s. 58).

\section{DEEUROPEIZACJA JAKO ODEJŚCIE OD EUROPEJSKICH WARTOŚCI}

Wartości Unii Europejskiej zdefiniowane zostały w art.2 Traktatu o Unii Europejskiej. Stanowią one podstawowe założenia aksjologiczne, na gruncie których powstaje wspólnota oparta nie tylko na indywidualnym interesie, lecz również umocowana we wspólnie rozumianej przestrzeni filozoficzno-prawnej. Odejście od wspomnianych wartości traktowane jest zatem jako proces deeuropeizacji, w którym odrzuca się aksjologiczne założenia umożliwiające europeizację.

Podobny pogląd prezentuje Piotr Mazurkiewicz, a za nim również J. Zimny, sytuując kwestię europeizacji i deeuropeizacji w kontekście tożsamości europejskiej. P. Mazurkiewicz definiuje tożsamość europejską w sensie idealnym (Jaka Europa powinna być?) i realnym (Jaka Europa rzeczywiście jest?) (s. 16). Jak pisze: „Tożsamość owa [europejska - S.D.], odnosząca się do kontynentu kultury, stanowi pewien kanon idei i wartości, z których najważniejsza jest personalistyczna 
wizja człowieka. Znajduje ona swój współczesny wyraz również w dziedzinie politycznej, jako przywiązanie do idei demokratycznego państwa prawnego". Stąd proces utrwalania bądź to rozluźniania więzi „między ideą a tożsamością europejską pozwala mówić o „europeizacji” i „deeuropeizacji” Starego Kontynentu w zależności od tego, czy proces rozwoju jego rzeczywistej tożsamości zmierza w kierunku realizacji owej idei, czy też w stronę przeciwną. Odstąpienie od tych tradycyjnych wartości przez większość mieszkańców Starego Kontynentu mogłoby być postrzegane właśnie jako deeuropeizacja Europy" (Mazurkiewicz, s. 16-17, także Zimny, 2007 s. 128-130). Owe zagrożenia J. Zimny dostrzega w istniejącym trendzie odejścia od tradycyjnych wartości oraz wobec wyzwań przed procesem integracji europejskiej związanych z upadkiem komunizmu oraz rosnącą różnorodnością społeczeństw (2007).

W tym miejscu należy zauważyć namacalną obecność wątku środkowo i wschodnio europejskiego, który stawia znak równości między demokratyzacją a europeizacją. Dla państw, które równolegle przechodziły przez okres demokratyzacji i dołączyły do procesu integracji, charakterystyczne jest traktowanie tych dwóch procesów jako równorzędnych, szczególnie za sprawą kryteriów kopenhaskich. Właśnie w ten sposób Attila Agh (2015) stawia znak równości między demokratyzacją i europeizacją a de-demokratyzacją i de-europeizacją. Rozpoznając rosnącą różnicę między formalną a prawdziwą (substantial) demokracją, uwypukla trendy, które nakładają się na proces de-demokratyzacji i de-europeizacji (s. 7). Dopatrując się jej korzeni w wyborach parlamentarnych z 2010 r. na Węgrzech, Agh identyfikuje proces ustanowienia demokracji fasadowej, którą nazywa jeszcze Potiomkinowską. W swojej istocie sprowadza się ona do rządów jednej partii, która po wyborach z 2014 r. przeistoczyła system w wybieralną autokrację (Agh, 2015). Charakterystycznymi cechami tego systemu są scalanie wpływów politycznych i gospodarczych oraz oligarchizacja systemu politycznego.

W podobny sposób, chociaż w znacznie szerszym kontekście, Nancy Borneo identyfikuje te same procesy, wprowadzając termin regresu demokratyzacji (democratic backsliding), który definiuje jako proces świadomego osłabiania lub eliminacji przez państwo istniejących instytucji podtrzymujących demokrację (Borneo, 2016, s. 5-19). Uzasadnienie użycia tego terminu stanowi fakt, że mamy do czynienia z ewolucją procesu podważania demokracji. Dzisiaj proces ten cechują zamachy oparte na obietnicach (promisory coups), przesadne rozdmuchanie kompetencji egzektutywy (executive aggrandizement), strategiczne szykanowanie i manipulacja (strategic harrassment and manipulation). Regres 
demokracji może prowadzić do jej załamania lub do poważnego osłabienia instytucji demokratycznych. Tak też rozumuje Roman Kuźniar, dla którego deeuropeizacja to właśnie proces odejścia od zasad i modelu funkcjonowania państwa, który został ukonstytuowany w procesie odzyskania niepodległości po 1989 r. oraz w trakcie procesu przystąpienia do Unii Europejskiej (Kuźniar, 2016). $\mathrm{Na}$ kwestię deeuropeizacji można również popatrzeć przez pryzmat koncepcji centrum-peryferie. Proces europeizacji, zauważa J. Grzymski (2010), często postrzegano w krajach dawnego bloku komunistycznego jako westernizację, która miała pociągać za sobą proces „twórczej/imitacyjnej linearnej przemiany w kraj demokratyczny, wolnorynkowy, zachodni”. Wówczas odejście od tych wartości może być postrzegane jako proces deeuropeizacji i jednoczesne spychanie danego państwa na peryferia Europy.

Definicja Raagmaa i in. (2014) zakłada, że jeżeli europeizacja to proces konwergencji z unijnymi wartościami i regulacjami, to proces deeuropeizacji można uznać za odejście od nich. Idąc tropem P. Mazurkiewicza, można przedstawić deeuropeizację jako subiektywny i negatywny opis procesów zachodzących w sprzeczności z wyobrażanym pozytywnym stanem rzeczy, dotyczącym całokształtu procesu integracji europejskiej.

\section{DEEUROPEIZACJA INSTYTUCJONALNA I PROCEDURALNA}

Jeżeli popatrzymy na europeizację przez pryzmat dogmatycznego instytucjonalizmu opisywanego przez T.G. Grosse, który sprowadza się do kwestii proceduralno-organizacyjnej, (2012, s. 9) i rozpoznamy, że w swojej istocie może on prowadzić do osłabienia jakości krajowego/lokalnego mechanizmu sprawowania władzy, można stwierdzić, że prowadzi do instytucjonalnej deeuropeizacji. Dzieje się tak dlatego, że w swojej istocie, niezależnie od poszukiwanego instytucjonalnego ujednolicenia na poziomie unijnym, osłabia, czy też zaburza funkcjonowanie jego poszczególnych części składowych (funkcjonowanie instytucji na szczeblu krajowym czy samorządowym). Takie działanie osłabia konstrukcję nośną europeizacji, która oparta jest na sprawnym funkcjonowaniu swoich części składowych, a tym samym osłabia również sam proces. $Z$ kolei deeuropeizację proceduralną można określić jako proces naruszania unijnych zasad (kompetencje, zasada subsydiarności), którego skutki w dłuższej perspektywie mają negatywny wpływ na części składowe biorące udział w procesie integracji. 
Schmid (2016) mówi o bezgranicznym dążeniu unijnej biurokracji do zawłaszczania kompetencji (s. 86). Nie mówimy już zatem o świadomym i dobrowolnym przekazywaniu kompetencji w ramach permissive consensus, które ustawia unijne instytucje w podrzędnej roli wobec państw członkowskich, lecz o dominującym, odgórnym, selektywnym i często przypadkowym podbieraniu kompetencji państwom narodowym. Jednym ze skutków takiego działania jest zaskoczenie, marazm, apatia czy też frustracja na poziomie lokalnym, regionalnym czy też krajowym, która w swojej istocie jest deeuropeizacją, jeżeli jest wywołana przez proces europeizacji.

\section{AKOMODACJA JAKO DEEUROPEIZACJA (DEEUROPEIZACJA MIMETYCZNA)}

Jak już była mowa wyżej, europeizacja między innymi zakłada, że w ramach tego procesu dochodzi do przeniesienia praktyk narodowych na poziom unijny, czyli sprzężenia zwrotnego. Jeśli jednak te praktyki są sprzeczne albo zmieniają proces integracji w sposób niekorzystny, należy zadać pytanie, czy nadal mamy do czynienia z europeizacją czy z deeuropeizacją?

Idąc tropem rozumowania C. Radaellego, Agnieszka Ciańciara (2015) zauważa, że ,im bardziej autorytarny system polityczny i większa kontrola elit politycznych nad gospodarką oraz im większe korzyści czerpane przez elity z tej symbiozy, tym mniejsze prawdopodobieństwo transferu unijnych reguł gry, które wprost zagrażają przetrwaniu elit politycznych i gospodarczych"(s. 10-11). Powstaje zatem pytanie, czy w systemach politycznych o niedokończonej transformacji, czy też w tych doświadczających democratic backsliding ograniczenia europeizacyjnego oddziaływania, nie prowadzą w swojej istocie do deeuropeizacji? Innymi słowy, czy oddziaływanie zewnętrzne w swojej istocie nie wpływa na legitymizację tychże nieeuropeizowalnych elit? Analizując drogę szeregu państw do Unii Europejskiej po upadku komunizmu, należy zaznaczyć, że nawet, jeżeli przykładów dla takich obaw nie brakuje, to i tak, jeden po drugim, te kraje stają się członkami Unii Europejskiej. Przyjmując, że w tym czasie mamy do czynienia z akomodacją, rozumianą jako dostosowywanie się zarówno państwa członkowskiego, jak i Unii Europejskiej, można stwierdzić, że swojej istocie stanowi ona kwintesencję deeuropeizacji, ponieważ jednocześnie mamy do czynienia z akomodacją, w której wzorce będące celem zmian, dostosowują się do nowej rzeczywistości. Chyba najtrafniejszą analogią w tym przypadku jest 
„nietrafiona antybiotykoterapia”. Stosując terminologię Agha, można uznać, że następuje formalna europeizacja (tworzenie odpowiednich instytucji, wdrażanie odpowiednich poleceń z Brukseli, czy nawet używanie unijnego żargonu), przy jednoczesnej prawdziwej deeuropeizacji (akomodacji patologicznych praktyk na poziomie krajowym, pielęgnacja korupcji, nieudolnego wymiaru sprawiedliwości, czy nawet manipulacji wyborczych). W swojej istocie następuje nie tylko proces dostosowania do unijnej rzeczywistości, ale również legitymizacja patologii na poziomie lokalnym, które obniżają wartość całego procesu i kumulują dezaprobatę wśród innych państw członkowskich.

\section{PODSUMOWANIE}

Celem niniejszego artykułu było podjęcie próby wyjaśnienia, czym jest deeuropeizacja i w jakim wymiarze może ona być traktowana jako antonim dla europeizacji. Powyższe rozważania nad naturą i istotą deeuropeizacji pozwalają dojść do następujących konkluzji. Jej źródeł można doszukiwać się w intelektualnej ułomności, która w euforii towarzyszącej europeizacji marginalizuje negatywne skutki procesu, które w swojej istocie mogą mieć daleko idące konsekwencje nie tylko dla samego procesu integracji, ale i dla jego części składowych (struktury administracyjne, społeczeństwa, jednostka). Należy przy tym z ostrożnością podchodzić do pokusy uznania deeuropeizacji za lustrzane odbicie europeizacji in toto. Uwzględniając wielowątkowość procesu europeizacji, warto zwrócić uwagę, że nie zawsze europeizacja musi mieć swoją reakcję. Jak już była mowa wyżej, nieeuropeizacja, czy też brak europeizacji, nie jest jeszcze jej antytezą.

Zarówno w przypadku europeizacji, jak i deeuropeizacji, teoretyczne modele pojawiają się na gruncie obserwacji i badań rzeczywistości. Dlatego na deeuropeizację można spojrzeć jak na proces zachodzący w wielu płaszczyznach, który spełnia chociaż jeden z poniższych kryteriów. Po pierwsze w swojej istocie proces ten osłabia więzi utworzone $\mathrm{w}$ ramach europeizacji. Po drugie demontuje części składowe na niższych szczeblach (krajowy, regionalny, lokalny, społeczny), podważając tym samym środowisko, w którym rozwija się proces europeizacji, czyli prowadzi do dystrofii swoich fundamentów. Po trzecie, umożliwia przedostanie się czynników osłabiających europeizację.

Wartość rozpoznania deeuropeizacji jako zwartej koncepcji w studiach europejskich pozwala wzmocnić ich funkcję diagnostyczną o przejrzyste i mierzalne narzędzie. Można pozostać w nadziei, że dalsze wysiłki na rzecz rozpoznania 
kolejnych wymiarów deeuropeizacji poszerzą horyzonty wiedzy na temat procesu integracji i uwolnią go od pułapek samouwielbienia i bezkrytycznego entuzjazmu.

\section{BibLIOGRAFIA:}

Agh, A., (2015). De-europeanization and de-democratization trends in ECE: From the Potemkin Democracy to the Elected Autocracy in Hungary. Journal of Comparative Politics, 8(2), 4-26.

Bache, I., George, S., Bulmer, S. (2011). Politics in the European Union, $3^{\text {rd }}$ ed. Oxford: Oxford University Press.

Borneo, N. (2016). On Democratic Backsliding. Journal of Democracy, 27(1), 5-19.

Börzel, T.A., Risse, T. (2009). The European Union and the Diffusion of Ideas, TheTransformative Power of Europe. Pobrane z: http://userpage.fu-berlin.de/ kfgeu/kfgwp/ wpseries/WorkingPaperKFG_1.pdf.

Chryssochoou, D.N. (2010). Europe's Contested Democracy. W: M. Cini, N. Perez-Solorzano Borragan (red.). European Union Politics. Oxford: Oxford University Press

Cianciara, A., Burakowski, A., Olszewski, P., Wódka, J. (2015). Europeizacja partii politycznych i grup interesu w wybranych krajach partnerstwa wschodniego i kandydujących do Unii Europejskiej. Warszawa: Instytut Studiów Politycznych Polskiej Akademii Nauk.

Czachur, W. (2010). Niemcy - wzlot, zagubienie czy upadek supergwiazdy? Pobrane z: http://www.geopolityka.org/analizy/waldemar-czachur-niemcy-wzlot-zagubienieczy-upadek-supergwiazdy.

Copeland, P. (2016). Europeanization and De-Europeanization in UK Employment Policy: changing Governments and Shifting Agendas. Public Administration, 94(4), 1124-1139.

Domaradzki, S. (2013). Bałkański dylemat Brukseli. O europeizacji Bułgarii czy bułgaryzacji Unii Europejskiej. W: E. Haliżak, M. Pietraś (red.). Poziomy analizy stosunków międzynarodowych (s. 423-446). Warszawa: Wydawnictwo Rambler.

Eigmüller, M., Mau, S. (2010). Gesellschaftstheorie und Europapolitik: Sozialwissenschaftliche Ansätze zur Europaforschung. Berlin: Springer.

Featherstone, K. (2003). Introduction: In the name of Europe. W: K. Featherstone, C.M. Radaelli (red.). The Politics of Europeanization (s. 3-26). Oxford: Oxford University Press.

Gąsior-Niemiec, A. (2005). Pojęcie Europeizacji. Wybrane problemy teoretyczne i metodologiczne - część 1. Polityka i Społeczeństwo, 2, 73-78.

Graziano, P., Vink, M. (2012). Europeanization: Concept, Theory, and Methods. W: S. Bulme, C. Lesquene (red.). The Member States of the European Union. Oxford: Oxford University Press. 2012.

Grosse, T.G. (2012). W objęciach Europeizacji. Warszawa: Instytut Studiów Politycznych PAN. Grzymski, J. (2010). O powrocie Polski do Europy. Przyczynek do rekonceptu- 
alizacji dychotomii centrum - peryferie. Kultura i Polityka: zeszyty naukowe Wyższej Szkoły Europejskiej im. ks. Józefa Tischnera w Krakowie, 7, 53-66.

Jacquot, S, Woll C., (2003). Usage of European Integration - Europeanization from Sociological Perspective. European Integration online Papers, 7(12). Pobrane z: http://eiop.or.at/eiop/texte/2003-012a.htm.

Jańczak, J. (2014). Przeciweuropeizacja jako kategoria badawcza w studiach nad procesami integracji europejskiej. W: A. Pacześniak, R. Riedel (red.). Europeizacja - mechanizmy, wymiary, efekty (s. 94-105). Toruń: Wydawnictwo Adam Marszałek. Krasnodębski, Z., (2013). Deeuropeizacja Europy. Do Rzeczy: Tygodnik Lisickiego, 11, $57-60$.

Kröger, S., Bellamy, R. (2014). Beyond Constraining Dissensus?: The Role of National Parliaments in Politicizing European Integration. Pobrane z: http://www.cis. ethz.ch/content/dam/ethz/special-interest/gess/cis/cis-dam/News_Events/ Events_2014/2014_CIS_Colloquium/2014_FS/Bellamy.pdf.

Kuźniar, R. (2016). Polska coraz bardziej poza Europą. Gazeta Wyborcza. Pobrane z: http://wyborcza.pl/magazyn/1,124059,19484056,polska-coraz-bardziej-poza-europa.html?disableRedirects=true.

Ladrech, R., (1994). Europeanization of Domestic Politics and Institutions: The Case of France. Journal of Common Market Studies, 32(1), s. 69-88.

Lemardeley, R. (2013). Democratic Deficit and Public Opinion in the EU: A Trust Issue? Pobrane z: http://www.nouvelle-europe.eu/node/1631.

Mair, P. (2004). The Europeanization Dimension. Journal of European Public Policy, 11(2), 337-348.

Mazurkiewicz, P. (2001). Europeizacja Europy, Tożsamość kulturowa w kontekście procesów integracji, Studium Generale Europa. Warszawa: Instytut Politologii, Uniwersytet Kardynała Stefana Wyszyńskiego.

Olsen, J.P. (2002). The Many Faces of Europeanization. Journal of Common Market Studies, 40(5), 921-952.

Pridham, G. (2006). European Union Accession Dynamics and Democratization in Central andEastern Europe: Past and Future Perspectives. Government and Opposition, 41(3), 373-400.

Radaelli, C.M. (2000). Whither Europeanization? Concept Stretching and Substantive Change. European Integration online Papers (EIoP), 4(8). Pobrane z: http://eiop.or.at/ eiop/texte/2000-008a.htm.

Riedel, R. (2014). Europeizacja - koncepcje i agenda badawcza. W: R. Riedel, A. Pacześniak (red.). Europeizacja - mechanizmy, wymiary, efekty (s. 21-37). Oslo-ToruńWrocław: Wyd. Uniwersytetu Wrocławskiego, University of Oslo i Wydawnictwa Adam Marszałek.

Raagmaa, G., Kalvet, T., Kasesalu, R. (2014). Europeanization and De-Europeanization of Estonian Regional Policy. European Planning Studies, 22(4), 775-795.

Romanowski, M. (2015). Polski łagodna de europeizacja. Pobrane z: http://gmf-warszawa.salon24.pl/681719,polski-wywazona-deeuropeizacja. 
Schimmelfennig, F. (2007). Europeanization Beyond Europe. Living Reviews in European Governance, 2(1). Pobrane z: http://www.livingreviews. org/lreg-2007-1.

Schimmelfennig, F., Rittberger, B. (2006). Theories of European Integration. Assumptions and Hypotheses. W: J.J. Richardson (red.). European Union: power and policy-making (s. 73-95). Abingdon; New York: Routledge.

Sedelmeier, U. (2011). Europeanization in New Member and Candidate States. Living Reviews in European Governance, 6(1).

Schmid, T. (2016). Europa umarła, niech żyje Europa! Biblioteka Polityki.

Schmidt, V.A. (1997). European Integration and Democracy: The Differences Among Memberstates. Journal of European Public Policy, 4(1), 128-145.

Sztompka, P. (2000). The Ambivalence of Social Change-Triumph or Trauma? WZB Papers, 00-001. Berlin: Wissenschaftszentrum Berlin für Sozialforschung (WZB). Pobrane z: http://hdl.handle.net/10419/50259.

Trenz, H.J. (2014). The Saga of Europeanization, On the Narrative Construction of a European Society. Arena Working, 7. Pobrane z: http://www.sv.uio.no/arena/ english/research/publications/arena-working-papers/2014/wp7-14.pdf.

Yilmaz, G. (2016). From Europeanization to De-Europeanization: The Europeanization Process of Turkey in 1999-2014. Journal of Contemporary European Studies, 24(1), $86-100$.

Zimny, J. (2007). Specyfika „Europejskiego nauczyciela” XXI wieku. Pedagogika katolicka, 1a, 128-130. Pobrane z: http://www.pedkat.pl/images/czasopisma/pk1a/art12.pdf. 